\title{
Overview of the Situation of Artisanal Brick Manufacturers in Mexico and Other Latin American Countries
}

\author{
María Neftalí Rojas-Valencia ${ }^{1 *}$ and Luciano Montiel Reyes ${ }^{2}$ \\ ${ }^{1}$ Universidad Nacional Autonoma de Mexico Instituto de Ingenieria, Mexico \\ ${ }^{2}$ Ingeniero Constructor, Chile.
}

Submission: November 22, 2017; Published: February 19, 2018

*Corresponding author : María Neftalí Rojas-Valencia, Universidad Nacional Autonoma de Mexico Instituto de Ingenieria, Ciudad De Mexico, Mexico, Email: mrojasv@iingen.unam.mx

\begin{abstract}
The urban growth that characterizes the most industrialized and developed areas of Mexico is a phenomenon that has benefited economically the companies dedicated to the building sector, and especially the ones focused on the manufacture and commercialization of building materials such as bricks. The lack of growth prevents the purchase of technology to improve productivity and reduce the environmental impact, creating a vicious circle that hampers business development and competitive improvement.
\end{abstract}

\section{Introduction}

A wide variety of organizations using industrial or artisanal processes take advantage of the growing demand for bricks in Mexico. As a result of the low professional development and high level of informality of the companies, the specific characteristics of artisanal manufacturing have led to a series of problems for the society and the organizations themselves [1]. The scarcity of training opportunities [1,2] in this economic sector contributes greatly to the lack of clarity of labor relations, insurance status, health and, in general, well-being of the workers' families [2,3]. In Mexico, approximately 17,000 artisanal manufacturers operating informally generate air pollution problems and emit green house gases [4].

Another problem is that $85 \%$ of artisanal manufacturing sites have a production capacity of fewer than 35,000 pieces per month, while the manufacturing capacity of industrial plantranges between 50,000 and 1,000,000 pieces per month. This situation causes a competitive disadvantage for artisanal companies which in turn limits the income and growth potential of these production units, leading to financial, technological, environmental and social stagnation $[2,3]$.

\section{The Brick Market}

In addition to the social and technological conditions of the brick manufacturing sector, additional circumstances, including market scenario, make the application of solutions even more complex.
The artisanal brick market is competitively perfect given the large number of suppliers and the price-accepting characteristic of the consumers. However, the benefits of the situation are mainly monopolized by the distributors (among which there are very few brick manufacturers because of the lack of capital to integrate a vertical supply chain).

Brick consumers tend to be self-builders, engineers and architects working in construction projects, and construction companies.

\section{Substitute Products}

Another of the external conditions affecting the economic development of artisanal brick manufacturers is the growing demand for substitute products, especially concrete blocks and prefabricated walls. These two products currently represent approximately $65 \%$ of the market forwall structural materials, while bricks barely represent approximately 25\%. Concrete block sales amount to $\$ 350$ billion pesos per year while brick sales only amount to $\$ 200$ billion pesos.

Moreover, there are some important differences in the operating strategies available to brick and concrete block manufacturers [4]:

a. Concrete block and cinder block manufacturers do not use kilns. Only $8 \%$ consume fuel and electric power while another $8 \%$ consume electric power exclusively. 


\section{Civil Engineering Research Journal}

b. Concrete blocks come in only 4 sizes while cinder blocks come in only 2 sizes regardless of the manufacturer and this situation allows the creation of a niche strategy.

c. Block manufacturer scan market their products under the Business to Customer model because of the small manufacturing investment required. This represents a production and commercial advantage against artisanal brick manufacturers because of the lower logistics costs involved.

In terms of market opinion, consumers indicate that blocks offer several advantages compared to bricks, especially as regards efficiency, quality, thermal conductivity, environmental friendliness, certificates, availability, resistance, affordability, standardization, durability and production speed.

Finally, the artisanal brick sector faces two challenges: on the one hand, the need to develop manufacturing policies more environmentally friendly and, on the other hand, the requirement to formalize the activity to gain access to better financing conditions permitting its development and growth.

The artisanal brick worker has to be informed about the environmental and labor risks associated with his activity and measures have to be taken to deal with them so that he can become a transforming agent contributing to mitigate or eliminate the adverse effects of his activity on health and environment.

\section{References}

1. Ruiz PC (2017) Estrategias para la reducción de emisiones del sector ladrillero en el marco de la Política de Prevención y Control de la Contaminación del Aire, Colombia Ponencias Tercer Foro PAN LAC, Tlaquepaque, Jalisco, México 17 - 20 de Octubre (In Spanish).

2. Pablo A León Madariaga (2017) Estudio de la Cadena de Valor del Sector Ladrillero en el Estado de Jalisco, Centro de Investigaciones Económicas y Sociales (CIES-UAG), Universidad Autónoma de Guadalajara. Ponencias Tercer Foro PAN LAC, Tlaquepaque, Jalisco, México 17 - 20 de Octubre.

3. Aranda A (2017) Programa Integral de Fortalecimiento al Sector Productivo de Ladrillo Artesanal, Secretaria de Medio Ambiente y Desarrollo Territorial, México. Ponencias Tercer Foro PAN LAC, Tlaquepaque, Jalisco, México 17 - 20 de Octubre.

4. INECC (2016) Regional Level Market Analysis of the Construction Sector and Pilot Project Based on a Public Policy Portfolio in Order to Reduce SLCPof Traditional Brickyards in Mexico. INECC, Mexico City, Mexico, end report, p. 1. 